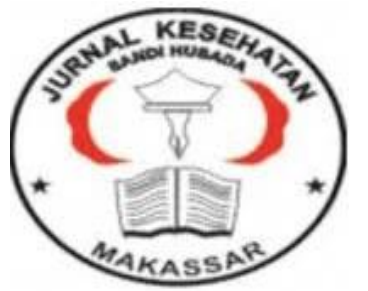

Jurnal Ilmiah Kesehatan Sandi Husada

hhttps://akper-sandikarsa.e-journal.id/JIKSH

Volume 9, Nomor 2, Desember 2020, pp 927-931

p-ISSN: 2354-6093 dan e-ISSN: 2654-4563

DOI: $10.35816 /$ jiskh.v10i2.438

\title{
Dampak Dehidrasi Saat Masa Kehamilan
}

ARTIKEL REVIEW

Impact of Dehydration During Pregnancy

Erlicha Paramitha Maryanto

Pendidikan Dokter, Fakultas Kedokteran, Universitas Lampung

\section{Artikel info}

Artikel history:

Received; Juli 2020

Revised: Agustus 2020

Accepted; September 2020

\begin{abstract}
Abstrak.
Latar belakang: Air merupakan hal yang vital untuk seseorang dan berfungsi sebagai penjaga hemostasis sel. Komposisi cairan dalam tubuh berubah selama masa kehamilan demi mendukung pertumbuhan dan perkembangan janin dalam kandungan. Keadaan fisiologis yang dialami wanita hamil dapat mempengaruhi keseimbangan cairan tubuh yang akan berefek pada status hidrasi wanita hamil. Di Indonesia ditemukan sebanyak $57.1 \%$ wanita hamil mengalami dehidrasi. Dehidrasi adalah keadaan terjadinya ketidakseimbangan cairan tubuh dimana tubuh kehilangan cairan lebih banyak daripada asupan cairan yang masuk ke dalam tubuh. Meteode: Penelitian ini menggunakan metode studi literatur dengan pencarian kata kunci "kehamilan", "dehidrasi", "status hidrasi". Hasil: Dampak yang ditimbulkan dari dehidrasi selama masa kehamilan adalah gangguan pertumbuhan dan perkembangan janin, penurunan volume ketuban, infeksi saluran kemih, dan konstipasi. Simpulan: Pencegahan akan kekurangan cairan harus dilakukan dengan cara konsumsi air yang cukup yaitu $3 \mathrm{~L} /$ hari yang bersumber dari minuman atau makanan dengan kelembaban tinggi dan memenuhi kebutuhan asupan zat gizi.
\end{abstract}
Abstract
Background: Water is important for a person and has a function to maintain cell hemostasis. The composition of fluids in the body changes during pregnancy to support the growth and development of the fetus in the womb. Physiological conditions experienced by pregnant women can affect the balance of body fluids which will affect the hydration status of pregnant women. In Indonesia, it is found that $57.1 \%$ of pregnant women are dehydrated. Dehydration is a condition where the body loses more fluids than the fluids intake. Methods: This study used a literature study method with the keywords "pregnancy", "dehydration", "hydration state". Results: The effects of dehydration during pregnancy include impaired fetal growth and development, decreased amniotic volume, urinary tract infections, and constipation. Conclusion: Prevention of lack of fluids 
must be done by consuming enough water, namely 3 L / day, which comes from drinks or foods with high humidity and meets the needs of nutritional intake.

Keywords:

Kehamilan;

Dehidrasi;

Status hidrasi;
Corespondent author:

Email: erlichamitha31@gmail.com

artikel dengan akses terbuka dibawah lisensi CC BY -4.0

\section{Pendahuluan}

Sebagian besar komponen tubuh manusia disusun oleh air. Air merupakan hal yang vital untuk seseorang dan berfungsi sebagai penjaga hemostasis sel. Adanya air juga berkontribusi dalam melarutkan komponen glukosa, ion, asam amino, sebagai pengangkut nutrisi dan zat sisa, menjadi campuran dengan mukosa, serta membantu menjaga suhu tubuh dari perubahan suhu lingkungan sekitar. Asupan cairan ke dalam tubuh dapat dipengaruhi oleh usia, kondisi lingkungan, aktivitas fisik, hingga jumlah makanan yang dikonsumsi. Jika asupan cairan ini tidak cukup terpenuhi akan terjadi dehidrasi (Kusuma, 2020).

Dehidrasi adalah keadaan terjadinya ketidakseimbangan cairan tubuh dimana tubuh kehilangan cairan lebih banyak daripada asupan cairan yang masuk ke dalam tubuh. Dehidrasi akibat kekurangan cairan dapat disebut sebagai hipernatremia atau hiponatremia apabila terjadi dengan adanya hiperglikemia. Dalam beberapa kasus, dehidrasi terjadi bukan hanya karena kekurangan air namun dapat terjadi dengan sebab adanya suatu penyakit atau dalam pengobatan (Subudhi, Askew, \& Luetkemeier, 2012). Komposisi cairan dalam tubuh berubah selama masa kehamilan demi mendukung pertumbuhan dan perkembangan janin dalam kandungan. Sebanyak 50\% wanita hamil dilaporkan mengalami mual dan muntah pada trimester pertama (Widen \& Gallagher, 2014). Prevalensi kejadian dehidrasi pada wanita hamil di Yunani adalah 34\%. Kejadian dehidrasi yang dialami wanita hamil meningkat setiap trimester yaitu 30\% pada trimester pertama, trimester kedua 33\%, dan trimester ketiga dengan 39\% (Malisova et al., 2014).

Keadaan fisiologis yang dialami wanita hamil dapat mempengaruhi keseimbangan cairan tubuh (seperti natrium dan kalium) yang akan berefek pada status hidrasi wanita hamil. Di Indonesia ditemukan sebanyak 57.1\% wanita hamil mengalami dehidrasi dengan riwayat mual dan muntah sebanyak 70.0\% (Mulyani, Hardinsyah, Briawan, \& Santoso, 2017). Setelah kehamilan, ada proses laktasi yang harus dialami wanita menyusui yang menyebabkan kehilangan banyak cairan. Mengingat akan dampak yang akan timbul pada wanita hamil sebagai kelompok berisiko saat mengalami dehidrasi maka penulis tertarik untuk melakukan penelitian seputar topik tersebut. Tujuan dari penulisan ini adalah untuk mengetahui lebih lanjut dampak-dampak yang ditimbulkan apabila terjadi dehidrasi saat kehamilan.

\section{Metode}

Penelitian ini menggunakan metode studi literatur yang merupakan metode penelusuran terhadap berbagai atikel yang relevan dengan topik penulisan. Artikel yang penulis dapatkan bersumber dari berbagai jurnal nasional dan jurnal internasional sebagai pembanding dengan indeks kata kunci wanita hamil/kehamilan (pregnancy), status hidrasi (hydation state) dan dehidrasi (dehydration) yang disusun terpisah atau dalam 
kombinasi sehingga tercipta hubungan yang logis. Pencarian artikel dibatasi dalam 10 tahun terakhir yaitu dari tahun 2010 hingga tahun 2020.

\section{Hasil Dan Pembahasan}

Proses kehamilan menyebabkan kenaikan berat badan hingga rata-rata $12 \mathrm{~kg}$ pada wanita dengan indeks massa tubuh normal. Kontribusi terbesar dari kenaikan berat badan ini adalah volume air dalam tubuh yang meningkat hingga 6-8 L. Tambahan cairan tubuh ini berada di cairan ketuban dan plasenta, volume cairan intraseluler dan ekstraseluler wanita hamil, serta berat janin sendiri yang terdiri dari 75-90\% air. Volume plasma darah yang meningkat selama masa kehamilan diperlukan untuk vaskularisasi plasenta sehingga memungkinkan terjadinya pertukaran nutrisi antara janin dan ibu sehingga membantu perkembangan janin. Ekspansi volume plasma juga berperan sebagai reservoir fisiologis jika terjadi perdarahan pada ibu (Harjanti, 2016).

Cairan ketuban berfungsi sebagai tempat penyimpanan air bagi janin beserta lingkungannya untuk media perkembangannya. Cairan amnion juga sebagai perlindungan terhadap trauma, perubahan suhu, dan infeksi bakteri, serta mendukung perkembangan paru-paru janin. Volume plasenta meningkat sebanding dengan berat janin selama masa gestasi. Peningkatan kadar air total ibu selama kehamilan diperlukan untuk perkembangan dan pertumbuhan janin (Halimatussakdiah \& Mediawati, 2012). Wanita di luar kehamilan rata-rata mengalami kekurangan cairan hingga 1,5-3 L/hari. Cairan tubuh yang keluar kebanyakan melalui urin dan kulit, atau bisa juga melalui jalur pernapasan dan sistem ekskresi (Symonds \& Ramsay, 2010). Sebanyak 50-70\% ibu hamil mengalami mual dan muntah saat awal kehamilan sehingga terjadi ketidakseimbangan asupan antara cairan yang masuk dan keluar. Padahal, kebutuhan air pada wanita hamil meningkat untuk memenuhi kebutuhan metabolisme bagi tubuhnya sendiri dan juga janin (Mulyani, Hardinsyah, Briawan, \& Santoso, 2018).

Penelitian yang dilakukan oleh Mulyani (2018) yang menilai status hidrasi wanita hamil dengan indikator osmolalitas urin mendapatkan bahwa nilai rerata pada dua kelompok yaitu hipohidrasi $(58,9 \%)$ dan normal $(41,1 \%)$ adalah $\geq 500 \mathrm{mOsm} / \mathrm{Kg}$. Hal tersebut menunjukkan bahwa responden mengalami dehidrasi. Osmolalitas urin adalah biomarker yang digunakan untuk menilai status hidrasi seseorang dalam kondisi tertentu. Selain osmolalitas urin, warna urin dapat menjadi salah satu indikator untuk menentukan status hidrasi pada anak-anak, ibu hamil, orang dewasa baik laki-laki, wanita, dan atlet (Armstrong et al., 2012).

Penelitian yang dilakukan oleh Mulyani (2018) mendapatkan adanya hubungan antara dehidrasi pada wanita hamil trimester ketiga terhadap berat badan dan panjang bayi $(\mathrm{p}<0,05)$. Dari dua kelompok yang diteliti yaitu 51,5\% kelompok dehidrasi dan 48,5\% kelompok normal, dihitung perbedaan berat badan lahir dan panjang badan bayi yaitu 596, 1gram dan 1,8 cm yang berarti berat badan lahir dan panjang badan bayi pada ibu dehidrasi lebih rendah dibandingkan ibu hamil normal. Puncak pertumbuhan janin adalah dalam rentang waktu 32-34 usia kehamilan. Pada usia kehamilan 34-36 minggu pertumbuhan janin diperlambat karena adanya batasan ruang dalam rahim. Karena hal tersebut, pada trimester ketiga ibu hamil merasa lebih mudah kenyang dan kekurangan nafsu makan tetapi pada saat itu pula nutrisi dan keburuhan air masih sangat dibutuhkan untuk janin agar tetap berkembang. Untuk mencapai perkembangan janin yang normal, dibutuhkan fungsi plasenta yang sehat supaya transfer nutrisi dari ibu ke janin berjalan dengan baik (Forbes \& Westwood, 2010). 
Kualitas dan kuantitas nutrisi akan diserap dengan baik ke dalam tubuh dengan bantuan sistem hidrasi. Hidrasi berperan dalam mengatur vaskularisasi, pengaturan suhu tubuh, transportasi berbagai zat gizi ke dalam sel-sel tubuh. Selain itu, peran hidrasi juga diperlukan dalam pembuangan hasil metabolisme di dalam sel. Dengan memperhatikan jumlah dan kualitas asupan zat gizi terutama konsumsi air, angka kejadian stunting juga dapat diturunkan (Sari, Hardinsyah, \& Tanziha, 2015). Volume cairan ketuban berkaitan dengan kesejahteraan janin baik fungsinya sebagai perlindungan maupun mendukung perkembangan janin. Volume ketuban dapat dievaluasi dengan menggunakan amniotic fluid index (AFI). Status hidrasi dan asupan cairan yang masuk ke tubuh ibu hamil dapat mempengaruhi nilai AFI. Apabila asupan cairan berkurang maka indeks volume ketuban juga berkurang yang selanjutnya akan berpengaruh terhadap janin (Malhotra \& Bora, 2014).

Komplikasi paling umum terjadi saat kehamilan adalah adanya infeksi saluran kemih. Tanda infeksi saluran kemih adalah ditemukannya bakteri dalam urin yang dapat menimbulkan gejala maupun tidak/asimtomatik. Bakteriuria asimtomatik terjadi pada 210\% kehamilan dan lebih mudah berkembang menjadi pielonefritis dibandingkan dengan keadaan di luar kehamilan. Orang dewasa yang mengalami dehidrasi kronis berisiko lebih tinggi mengalami infeksi saluran kemih. Peningkatan asupan cairan dapat menurunkan risiko berulangnya kejadian infeksi dan memiliki efek kolonisasi bakteri pada saluran kemih (El-Sharkawy, Sahota, \& Lobo, 2015). Kelainan umum lainnya yang sering terjadi pada wanita hamil adalah konstipasi. Sebanyak 40\% wanita mengalami konstipasi pada masa kehamilannya. Beberapa faktor yang dapat menyebabkan konstipasi dalam kehamilan adalah perubahan hormonal dan asupan makanan serta cairan. Konstipasi dapat dicegah dengan konsumsi makanan tinggi serat dengan kombinasi asupan cairan yang cukup. Asupan air yang rendah dapat menurunkan massa dan frekuensi tinja sehingga dapat menimbulkan sembelit (Trottier, Erebara, \& Bozzo, 2012).

Tanda dehidrasi pada ibu hamil dapat diketahui jika frekuensi berkemih menurun, warna urin kuning pekat, timbul rasa haus dan mulut kering, sakit kepala, suhu tubuh tinggi, hingga dapat muncul kontraksi palsu. Kebutuhan cairan pada wanita hamil adalah sebesar $3 \mathrm{~L} /$ hari agar fungsi homeostasis bertahan dan memungkinkan untuk transportasi zat gizi ke dalam sel serta ekskresi dari produk sisa metabolisme. Cairan bisa didapatkan dari air maupun makanan yang memiliki kelembaban tinggi (Bardosono et al., 2016). Faktor sosial-ekonomi juga mempengaruhi daya beli bahan makanan dan minuman untuk memenuhi kebutuhan gizi selama kehamilan yang akan memberikan dampak pada hasil kehamilan. Menjaga hidrasi ini dilakukan supaya selama masa kehamilan ibu dapat terhindar dari berbagai komplikasi serius akibat dehidrasi (Alman, Coffman, Siega-Riz, \& Luben, 2017).

\section{Simpulan Dan Saran}

Dampak yang dapat timbul apabila terjadi dehidrasi saat kehamilan adalah gangguan pertumbuhan dan perkembangan janin, penurunan volume ketuban, infeksi saluran kemih, dan konstipasi. Peningkatan konsumsi air merupakan alternatif untuk perilaku dan gaya hidup yang lebih sehat. Perubahan fisiologis selama masa kehamilan menyebabkan asupan zat gizi dan cairan meningkat. Apabila ibu hamil tidak memenuhi kebutuhan cairan selama gestasi maka akan terjadi dehidrasi atau ketidakseimbangan cairan dalam tubuh. Pencegahan akan kekurangan cairan harus dilakukan dengan cara konsumsi air yang cukup yaitu 3 L/hari, membatasi konsumsi makanan dan minuman berkafein karena dapat memicu peningkatan frekuensi berkemih. 


\section{Daftar Rujukan}

Alman, B. L., Coffman, E., Siega-Riz, A. M., \& Luben, T. J. (2017). Associations between maternal water consumption and birth defects in the national birth defects prevention study (2000-2005). Birth Defects Research, 109(3), 193-202. https://doi.org/10.1002/bdra.23569

Armstrong, L. E., Johnson, E. C., Munoz, C. X., Swokla, B., Le Bellego, L., Jimenez, L., ... Maresh, C. M. (2012). Hydration Biomarkers and Dietary Fluid Consumption of Women. Journal of the Academy of Nutrition and Dietetics, 112(7), 1056-1061. https://doi.org/10.1016/j.jand.2012.03.036

Bardosono, S., Prasmusinto, D., Hadiati, D. R., Purwaka, B. T., Morin, C., Pohan, R., ... Guelinckx, I. (2016). Fluid intake of pregnant and breastfeeding women in Indonesia: A cross-sectional survey with a seven-day fluid specific record. Nutrients, 8(11), 1-11. https://doi.org/10.3390/nu8110651

El-Sharkawy, A. M., Sahota, O., \& Lobo, D. N. (2015). Acute and chronic effects of hydration

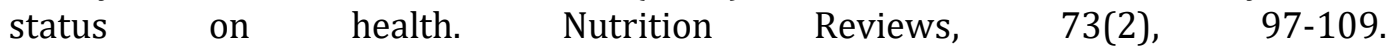
https://doi.org/10.1093/nutrit/nuv038

Forbes, K., \& Westwood, M. (2010). Maternal growth factor regulation of human placental development and fetal growth. Journal of Endocrinology, 207(1), 1-16. https://doi.org/10.1677/JOE-10-0174

Halimatussakdiah, H., \& Mediawati, M. (2012). Pengaruh Perubahan Fisiologis Ibu Hamil Terhadap Antropometri Bayi Baru Lahir di Aceh Besar. Idea Nursing Journal, 3(1), $32-41$.

Harjanti, A. I. (2016). Studi Komparatif Pengukuran LILA (Lingkar Lengan Atas) Dan IMT (Indeks Massa Tubuh) Dengan Berat Badan Pada Ibu Hamil KEK (Kekurangan Energi Kronik). Jurnal Ilmu Kebidanan Dan Kesehatan, 7(1). Retrieved from http://ejournal.bup.ac.id/index.php/jkeb/article/view/55

Kusuma, A. D. (2020). Penilaian Status Hidrasi. Jurnal Ilmiah Kesehatan Sandi Husada, 11(1), 13-17. https://doi.org/10.35816/jiskh.v11i1.196

Malhotra, N., \& Bora, R. (2014). Amniotic Fluid Index. In Ultrasound in Obstetrics and Gynecology (pp. 188-188). https://doi.org/10.5005/jp/books/12162_21

Malisova, O., Protopappas, A., Nyktari, A., Bountziouka, V., Antsaklis, A., Zampelas, A., \& Kapsokefalou, M. (2014). Estimations of water balance after validating and administering the water balance questionnaire in pregnant women. International Journal of Food Sciences and Nutrition, 65(3), 280-285. https://doi.org/10.3109/09637486.2013.860585

Mulyani, E. Y., Hardinsyah, Briawan, D., \& Santoso, B. I. (2017). Hydration status of pregnant women in West Jakarta. Asia Pacific Journal of Clinical Nutrition, 26(1), 26-30. https://doi.org/10.6133/apjcn.062017.s14

Mulyani, E. Y., Hardinsyah, H., Briawan, D., \& Santoso, B. I. (2018). Analisis Status Hidrasi dan Asupan Zat Gizi Serta Air pada Ibu Hamil. Media Kesehatan Masyarakat Indonesia, 14(3), 225. https://doi.org/10.30597/mkmi.v14i3.4343

Sari, A. E., Hardinsyah, \& Tanziha, I. (2015). Effect of water intake on sprague-dawley rat off spring's linear growth. Pakistan Journal of Nutrition, 14(7), 436-439. https://doi.org/10.3923/pjn.2015.436.439

Subudhi, A. W., Askew, E. W., \& Luetkemeier, M. J. (2012). Dehydration. In Encyclopedia of 
Human Nutrition (Vol. 2-4, pp. 1-9). https://doi.org/10.1016/B978-0-12-3750839.00068-4

Symonds, M. E., \& Ramsay, M. M. (2010). Maternal-Fetal Nutrition During Pregnancy and Lactation. United Kingdom: Cambridge University Press.

Trottier, M., Erebara, A., \& Bozzo, P. (2012). Treating constipation during pregnancy. Canadian Family Physician, 58(8), 836-838.

Widen, E. M., \& Gallagher, D. (2014). Body composition changes in pregnancy: Measurement, predictors and outcomes. European Journal of Clinical Nutrition, 68(6), 643-652. https://doi.org/10.1038/ejcn.2014.40 